
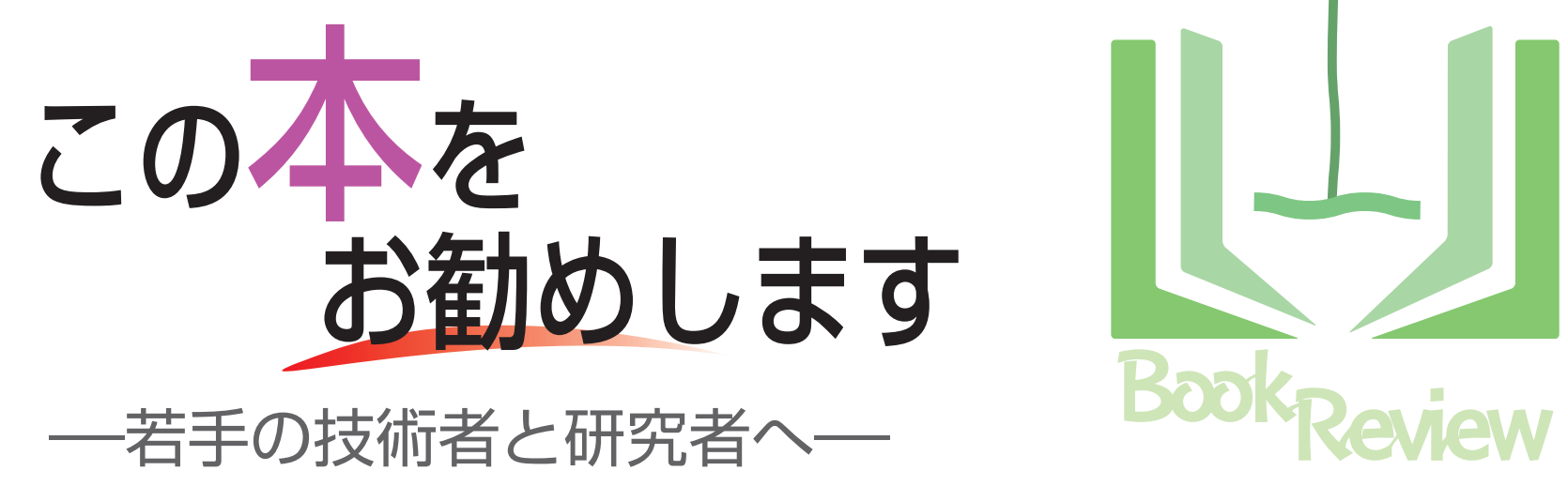

\title{
Review 01
}

\section{大江戸えねるぎ一事情}

石川英輔著

講談社，1993 年 7 月発行

320 ページ，560 円

ISBN-10 : 4-06-185431-3

ISBN-13 : 978-4-061-85431-4

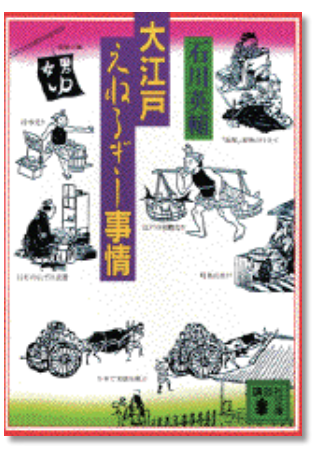

書評子が「大江戸シリーズ」の中で初めて手にした のは,この文庫本である. 本書では, エネルギ一消費 を軸に, 明かり, 暖房, 風呂, 料理, 生産, 兴の他の 生活の多くの場面について, 現在と江戸時代の生活ス タイルを比較している.

例えば，交通機関について，同じ距離を移動するの に必要なエネルギ一を徒歩と比べると, 電車は約 5 分 の 1 , バスで同じぐらい, 乗用車では約 5 倍掛かるら しい. 1990 年代前半のデー夕を元に比較しているの で, 現在ならもう少し違うデータになるかもしれない. この他に，ガス湯沸かし器を使う内湯と廃材を使う銭 湯も比較している．燃えかすの灰までも活用すること で特殊な薬剂を使用しない生活方法も書いている．江
戸時代は鎖国中であり，食料を含めあらゆる物資を自 給していたため, とにかく無駄がない.

日の出日の入りに合わせた毎日の時刻は昼間の明る さ，月齢に合わせた毎月の日は夜の明るさを表してい る. 作業に必要な明るさを思い浮かべながら予定を立 てることができる. 時計は季節に合わせて昼夜の回転 速度を変更する高度な機構を持つ必要があるが, から くりに努力するよりお天道様を見る方が早い. また, うるう年の 1 日追加のみでは地球の公転周期とうまく 同期できないため, うるう月を持つ年もあるから 1 年 が13か月になってしまう場合もあった光うだ.しかし, 自然に同期した生活なら, 使用する明かりは最小限で 済む.

不便さを補うために体を壊すことは考えものだが, 一方で，ちょっとした便利さのためにここまでエネル ギーコストを掛けているものかと気付かされる.「大江 戸シリーズ」は人気があり, この本の後にも, リサイ クル, 生活, 兰の他多くの題材を軸に, 同じ著者が執 筆を続けている. 更に, 実際に当時の生活を追体験し た本も出版されている. 生活の知恵, エネルギ一の在 り方, 便利さなど, 今の生活の在り方を考え直すとき, 物差しを当てる方向を定めるためにもう一つの点を定 めてくれる本である.

(小瀬木滋)

For young engineers and researchers 